\title{
Pathogenesis of Murine Lymphotropic Gammaherpesvirus Isolate 78
}

\author{
M. MRMUSOVÁ-ŠUPOLÍKOVÁ ${ }^{1}$, M. PAPPOVÁ ${ }^{1}$, J. MISTRÍKOVÁ ${ }^{1,2}$ \\ ${ }^{1}$ Department of Microbiology and Virology, Faculty of Natural Sciences, Comenius University, Bratislava, \\ Slovak Republic \\ ${ }^{2}$ Institute of Virology, Slovak Academy of Sciences, Bratislava, Slovak Republic
}

Received March 21, 2003

Accepted September 22, 2003

Abstract

Mrmusová-Šupolíková M., M. Pappová, J. Mistríková: Pathogenesis of Murine Lymphotropic Gammaherpesvirus Isolate 78. Acta Vet. Brno 2003, 72: 371-376

$\mathrm{BALB} / \mathrm{c}$ mice were infected intranasally with the mouse lymphotropic gammaherpesvirus isolate 78 (MHV-78). Infectious virus was detected in various organs of infected mice at different time intervals during a period of 180 days post infection (p.i.) by cocultivation with permissive VERO cells and indirect immunofluorescence using monoclonal antibodies prepared against MHV. We observed the highest infectious titer of MHV-78 during the acute infection on day 15 in lungs, and on days 7 and 15 in blood. At later intervals of infection the virus was detected in spleen, peritoneal macrophages, thymus, bone marrow and mammary glands. Furthermore, the analysis of differential white blood cell count of healthy/control and virus-infected BALB/c mice was followed. The obtained results showed that the infection with MHV-78 was accompanied with the changes in the number of leukocytes and quality of differential white blood cell count in correlation with the duration of infection. In comparison with control group, mice infected with MHV-78 had increased numbers of leukocytes with the higher numbers on days 15 and 122 p.i. and increased numbers of lymphocytes associated with the appearance of atypical leukocytes. In acute infection (up to day 30 p.i.) the frequency of atypical leukocytes increased, reaching a maximum at day 15 p.i. A similar increase in the frequency of these cells was observed in the course of persistent infection (after day 30 p.i.), reaching a maximum at day 122 p.i. Approximately $7 \%$ of $\mathrm{BALB} / \mathrm{c}$ mice infected with MHV-78 developed tumors. Cells derived from tumor were positive for viral antigen. These results showed that MHV-78 is lymphotropic, oncogenic and very similar with MHV-68, MHV-72, MHV-76, MHV-Šmava in some virological and pathogenetic features.

Mouse herpesvirus isolate 78, pathogenesis, lymphatic system, atypical leukocytes

Mouse herpesvirus isolate 78 (MHV-78) is a lymphotropic gammaherpesvirus representing an isolate of mouse herpesvirus strain 68 (MHV-68, species Murid herpesvirus 4, genus Rhadinovirus, subfamily Gammaherpesvirinae, family Herpesviridae) (van Regenmortel et al. 2000). MHV-78 infects wild rodents and can readily infect experimental mice. This virus has been isolated from a yellow-necked mouse Apodemus flavicollis (Blaškovič et al. 1980). MHV isolates are able to establish productive infection in fibroblast and epithelial cell lines derived from several mammalian species, including humans (Blaškovič et al. 1980; Svobodová et al. 1982). After intranasal or oral inoculations, MHV-68 spreads to lungs and then via hematogenous route to adrenal glands, spleen, liver, kidney, heart muscle, lymph nodes, thymus and bone marrow (SunilChandra et al. 1992a; Mistríková et al. 1994; Rajčáni et al. 1985, 1987). As demonstrated in immunocompetent mice infected by the intranasal route, the lungs are the main tissue productively infected with MHV, which replicates in the alveolar epithelium and in mononuclear cells (Sunil-Chandra et al. 1992a; Rajčáni et al. 1987). In addition, lifelong latent infection can be established in lymphatic organs, alveolar and peritoneal mononuclear cells, and lymphocytes and macrophages of peripheral blood (Mistrík ová et al. 1994; Sunil-Chandra et al. 1992b). MHV-68 is the most studied, the analysis and

Address for correspondence:

Doc. RNDr. J. Mistríková DrSc.

Department of Microbiology and Virology
Phone: +421 254773172

Fax: +421260296436

http://www.vfu.cz/acta-vet/actavet.htm 
sequencing of the MHV-68 genome have shown that several ORFs are in part homologous with or closely related to the DNA sequence of gammaherpesviruses such as Kaposi's sarcoma-associated herpesvirus (KSHV) or human herpesvirus 8 (HHV-8), Epstein-Barr virus (EBV) and herpesvirus saimiri (HVS) (Efstathiou et al. 1990ab; Mackett et al. 1997; Virgin et al. 1997). The polypeptide profile of MHV-78 has been found closely related to that of MHV-68. In comparison with other mouse herpesvirus isolates, MHV-78 lacked a polypeptide with apparent molecular weight of $46 \mathrm{kDa}$, the rest of polypeptides being identical well (Reichel et al. 1991). Already in regard to these small differences in poplypeptide profile of MHV-78 we decided to study this isolate. Therefore, the aim of study presented here was characterization of some virological and pathogenetical features of MHV-78 infection in BALB/c mice and assessment of similarities and differences between MHV-78 and the other MHV isolates.

\section{Materials and Methods}

Virus

MHV-78 stock was prepared by infection of VERO cells and harvesting at 72 or $96 \mathrm{~h}$ post infection (p.i.). Cells were disrupted and the virus was released by homogenization and sonication. The obtained viral suspension was clarified by low-speed centrifugation. The supernatant was stored at $-70^{\circ} \mathrm{C}$ until used. Infectious virus was assayed by plaque titration in VERO cells.

Animals

$\mathrm{BALB} / \mathrm{c}$ mice originating from Velaz (Prague, Czech Republic) were propagated at the Institute of Virology, Slovak Academy of Sciences, Bratislava, under standard housing conditions. Sixty female 4-6-week-old mice were inoculated intranasally (i.n.) with $2 \times 10^{5} \mathrm{PFU}(20 \mu \mathrm{l})$ of the virus per mouse under light anesthesia with ether. One family (8) newborn 2-3-day-old mice were inoculated orally with $1 \times 10^{5} \mathrm{PFU}(10 \mu \mathrm{l})$ of the virus per mouse. Thirty 4-6-week-old mice sham-infected mice served as controls.

Experiments with mice

Mice were killed at different times $(2,3,7,9,12,15,28,60,122,180$ d. p.i.) by cervical dislocation. The blood, lungs, spleen, thymus, liver, kidneys, lymph nodes, bone marrow and mammary glands were removed and used for preparation of cell suspensions for detection of viral antigen by immunofluorescence test. Specimens for detection of the virus were taken and stored at $-70{ }^{\circ} \mathrm{C}$ until virus titration.

Blood samples were taken from sinus orbitalis at different times $(2,3,7,9,12,15,28,60,122,180$ d. p.i.) and mixed instantly with heparin (final concentration of 2-4 U/ml) to prevent blood clotting.

Staining of blood elements

Blood smears were made immediately after blood collection. They were stained after fixation by air drying with May-Grünwald solution for $10 \mathrm{~min}$ and Giemsa-Romanovski solution for $15 \mathrm{~min}$. The number of leukocytes was determined after 10 min of staining with Türk solution.

Differential white blood cell count

Blood picture consisted of calculation of percentage of each kind of white blood cells.

Titration of infectious virus was done in VERO cells. Frozen homogenates of organs were thawed and clarified by a low-speed centrifugation and then diluted 10 -fold serially up to $10^{-6}$ in Dulbecco's Modified Eagle's Medium supplemented with $3 \%$ of heat-inactivated bovine serum, glutamine (300 mg/l) and gentamicine $(80 \mathrm{mg} / \mathrm{l})$. Each dilution $(0.1 \mathrm{ml}$ per culture vessel) was used for infecting VERO cell monolayers. After 3-7 days of incubation at $37^{\circ} \mathrm{C}$ in $5 \% \mathrm{CO}_{2}$ the monolayers were fixed and stained and the cytopathic effect (CPE) was evaluated.

Cytological examination

Infected cell cultures grown on glass cover slips were fixed in Carnoy solution for $15 \mathrm{~min}$ and then transferred to $96 \%$ ethanol. The fixed specimens were stained with hematoxylin-eosin.

Immunofluorescence (IF) test

The presence of the virus antigen in cells from organs of infected mice was determined by indirect IF test and the percentage of positive cells was calculated. Suspensions of cells (100 $\mu$ l) obtained from organ tissues of infected mice were stained with a monoclonal antibody (MAb) prepared against MHV diluted 1:100-1:500 and with a goat anti-mouse $\operatorname{IgG}(\mathrm{H}+\mathrm{L})$ conjugated with rhodamine (Immunotech, Slovak Republic). Suspensions of tumor cell line (derived from tumor developed in BALB/c mice 240 d.p.i. with MHV-78) were stained with polyclonal antibody, prepared against MHV, diluted 1:8, and with swain anti-rabbit IgG conjugated with FITC.

Monoclonal antibodies (MAb)were prepared in our laboratory (Gulášová et al. 2000). 


\section{Results}

MHV-78 was lethal for newborn suckling mice which died 17 days after oral infection in contrast to 4-6-week-old mice not showing apparent symptoms of illness. The presence of the virus was followed in the lymphatic system of 4-6-week-old female BALB/c mice infected intranasally with $2 \times 10^{5} \mathrm{PFU}$ of MHV-78 per mouse. Even if the virus was given in much higher doses to 4-6-week-old mice, they did not show apparent symptoms of illness. The infected mice were sacrificed on days 2-180 p.i. and samples of blood, lungs, spleen, thymus, peritoneal macrophages, kidneys, lymph nodes, bone marrow and mammary glands were taken. Days 2, 3, 7, 9, 12, 15, 28, 60, 122 and 180 p.i. were chosen for sacrifice on the basis of oer previous experiences with MHV-72 (Mi s trík ová et al. 1994) and MHVŠumava (Mistrík ová et al. 2002). Results of our experiments are demonstrated in Table 1, Figs. 1a, $1 \mathrm{~b}$ and 2 (Plates III and IV).

Table 1

Detection of infectious virus and viral antigen in 4-6-week-old BALB/c mice infected with MHV-78

\begin{tabular}{|c|c|c|c|c|c|c|c|c|c|c|c|}
\hline \multicolumn{12}{|c|}{ Day p.i. } \\
\hline Organ & & 2 & 3 & 7 & 9 & 12 & 15 & 28 & 60 & 122 & 180 \\
\hline \multirow[t]{2}{*}{ Blood } & $\mathrm{TCID}_{50} / \mathrm{ml}$ & $10^{1}$ & $10^{1}$ & $10^{2}$ & $10^{1}$ & $10^{1}$ & $10^{2}$ & $10^{1}$ & $10^{1}$ & 1 & 1 \\
\hline & $\mathrm{IF}^{50}$ & + & + & ++ & + & + & + & + & + & ND & ND \\
\hline \multirow[t]{2}{*}{ Lungs } & $\mathrm{TCID}_{50} / \mathrm{m}$ & $10^{1}$ & $10^{1}$ & $10^{1}$ & $10^{2}$ & $10^{2}$ & $10^{3}$ & $10^{2}$ & 1 & 0 & 0 \\
\hline & $\mathrm{IF}^{\mathrm{JO}}$ & + & + & + & ++ & ++ & +++ & ++ & + & - & - \\
\hline \multirow[t]{2}{*}{ Spleen } & $\mathrm{TCID}_{50} / \mathrm{ml}$ & 0 & 0 & 0 & 0 & 0 & 1 & $10^{1}$ & $10^{3}$ & $10^{2}$ & $10^{2}$ \\
\hline & IF & - & - & - & - & - & - & + & +++ & ++ & ++ \\
\hline \multirow[t]{2}{*}{ Thymus } & $\mathrm{TCID}_{50} / \mathrm{ml}$ & 0 & 1 & 0 & 1 & 1 & 1 & $10^{1}$ & $10^{1}$ & $10^{1}$ & $10^{1}$ \\
\hline & $\mathrm{IF}^{30}$ & - & - & - & - & - & + & + & + & + & + \\
\hline \multirow{2}{*}{$\begin{array}{l}\text { Peritoneal } \\
\text { macrophages }\end{array}$} & TCID $/ \mathrm{ml}$ & - & - & - & - & - & - & $10^{2}$ & $10^{1}$ & 0 & 0 \\
\hline & $\mathrm{IF}^{50}$ & - & - & - & - & - & - & + & - & + & + \\
\hline \multirow[t]{2}{*}{ Kidneys } & $\mathrm{TCID}_{50} / \mathrm{ml}$ & 0 & 0 & 1 & 1 & 1 & 1 & 0 & 0 & 0 & 0 \\
\hline & $\mathrm{IF}^{30}$ & - & - & - & - & - & - & - & - & - & - \\
\hline \multirow[t]{2}{*}{ Lymph nodes } & $\mathrm{TCID}_{50} / \mathrm{ml}$ & - & - & - & - & 1 & $10^{1}$ & 1 & 1 & - & 0 \\
\hline & $\mathrm{IF}^{30}$ & ND & ND & ND & ND & - & + & + & - & ND & - \\
\hline \multirow[t]{2}{*}{ Bone marrow } & $\mathrm{TCID}_{50} / \mathrm{ml}$ & 0 & 0 & 0 & 0 & 0 & 1 & $10^{1}$ & $10^{1}$ & $10^{1}$ & 0 \\
\hline & $\mathrm{IF}^{\mathrm{O}}$ & - & - & - & - & - & + & ++ & + & + & - \\
\hline \multirow[t]{2}{*}{$\begin{array}{l}\text { Mammary } \\
\text { glands }\end{array}$} & $\mathrm{TCID}_{50} / \mathrm{ml}$ & - & - & - & - & - & - & $10^{1}$ & $10^{1}$ & $10^{2}$ & $10^{1}$ \\
\hline & $\mathrm{IF}^{30}$ & - & - & - & - & - & - & + & + & ++ & + \\
\hline
\end{tabular}

Mice were infected i.n. with $2 \times 10^{5} \mathrm{PFU}$ of MHV-78 per mouse. IF = immunofluorescence evaluated as (-) for all cells negative, as (+) for $2-4 \%$ of cells positive, as (++) for $4-10 \%$ of cells positive, and as (+++) for $50 \%$ of cells positive. $0=$ no virus detected either in the $1^{\text {st }}$ or in the $2^{\text {nd }}$ cell culture subpassage. ND = not done.

Infectious virus and virus antigen was detected by cocultivation with permissive VERO cells and indirect immunofluorescence using monoclonal antibodies prepared against MHV in the investigated organs from day 2 p.i. We detected the highest infectious titer of MHV78 during the acute infection on day 15 in lungs and on days 7 and 15 in blood. We also observed the highest titer of MHV-78 on days 60, 122 and 180 p.i. in spleen. Furthermore, we detected the virus in mammary glands on days $28,60,122$ and 180 p.i. The presence of the virus in the lungs after i.n. inoculation was examined indirectly by infecting VERO cells with suspension obtained from lungs of MHV-78 infected mice $72 \mathrm{~h}$ p.i. (Fig. 1a). The presence of the virus antigen in spleen was demonstrated by IF test Fig. 2. In the second part of our study the analysis of differential white blood cell count of healthy/control and virusinfected BALB/c mice was followed (Tables 2, 3). The obtained results showed that the infection with MHV-78 was accompanied by changes in the number of leukocytes and 
quality of differential white blood cell count in correlation with the duration of infection. During the acute infection the frequency of atypical leukocytes increased, reaching a maximum of $13 \%$ at day 15 p.i. (Table 2, Plate IV, Fig. 3). Following the acute infection a persistent infection was established. A similar increase in the frequency of atypical leukocytes was observed in the course of persistent infection, reaching a maximum of $9 \%$ at day 122 p.i. (Table 2). In comparison with control group, mice infected with MHV-78 had slightly increased numbers of leukocytes with higher numbers on days 15 and 122 p.i. and decreased lymphocytes associated with the increasing number of atypical leukocytes (Tables 2,3). Regarding other blood cells, the frequencies of segmented and non-segmented cells were slightly increased in the group of infected mice in comparison with the group of control mice. Infection with MHV-78 did not induce substantial changes in numbers of monocytes, basophils and eosinophils. During acute and chronic phase of infection we did not observe significant splenomegaly. Between 240 and 360 d.p.i. 4 out of 60 of infected $\mathrm{BALB} / \mathrm{c}$ mice developed tumors. Connection between infection and tumor development was confirmed by detection of viral antigen in tumor cell line (Plate V, Figs 4, 5).

Table 2

Effect of MHV-78 infection on differential white blood cell count of BALB/c mice

\begin{tabular}{|lcccccccccc|}
\hline Day post infection & 2 & 3 & 7 & 9 & 12 & 15 & 28 & 60 & 122 & 180 \\
\hline Leukocytes/ul & 7800 & 8050 & 8000 & 8800 & 9600 & 15800 & 9400 & 7800 & 13100 & 8600 \\
Monocytes & $0 \%$ & $3 \%$ & $1 \%$ & $1 \%$ & $0 \%$ & $0 \%$ & $0 \%$ & $1 \%$ & $1 \%$ & $0 \%$ \\
Lymphocytes & $58 \%$ & $45 \%$ & $60 \%$ & $63 \%$ & $68 \%$ & $62 \%$ & $72 \%$ & $70 \%$ & $66 \%$ & $70 \%$ \\
Segmented neutrophiles & $15 \%$ & $20 \%$ & $23 \%$ & $18 \%$ & $16 \%$ & $19 \%$ & $16 \%$ & $15 \%$ & $10 \%$ & $12 \%$ \\
Non-segmented neutrophiles & $25 \%$ & $27 \%$ & $10 \%$ & $12 \%$ & $14 \%$ & $5 \%$ & $9 \%$ & $11 \%$ & $14 \%$ & $15 \%$ \\
Basophils & $0 \%$ & $0 \%$ & $0 \%$ & $1 \%$ & $0 \%$ & $0 \%$ & $0 \%$ & $0 \%$ & $0 \%$ & $0 \%$ \\
Eosinophils & $0 \%$ & $1 \%$ & $1 \%$ & $0 \%$ & $0 \%$ & $1 \%$ & $1 \%$ & $0 \%$ & $0 \%$ & $0 \%$ \\
Atypical leukocytes & $2 \%$ & $4 \%$ & $5 \%$ & $5 \%$ & $2 \%$ & $13 \%$ & $2 \%$ & $3 \%$ & $9 \%$ & $3 \%$ \\
\hline
\end{tabular}

Table 3

Differential white blood cell count of control BALB/c mice

\begin{tabular}{|lcccccccccc|}
\hline Day & 2 & 3 & 7 & 9 & 12 & 15 & 28 & 60 & 122 & 180 \\
\hline Leukocytes/ul & 7000 & 6800 & 6500 & 8100 & 7100 & 6800 & 8000 & 6300 & 6000 & 7800 \\
Monocytes & $1 \%$ & $2 \%$ & $1 \%$ & $0 \%$ & $2 \%$ & $2 \%$ & $3 \%$ & $1 \%$ & $2 \%$ & $3 \%$ \\
Lymphocytes & $70 \%$ & $73 \%$ & $72 \%$ & $80 \%$ & $77 \%$ & $81 \%$ & $80 \%$ & $77 \%$ & $78 \%$ & $81 \%$ \\
Segmented neutrophiles & $14 \%$ & $15 \%$ & $21 \%$ & $14 \%$ & $13 \%$ & $12 \%$ & $8 \%$ & $14 \%$ & $11 \%$ & $13 \%$ \\
Non-segmented neutrophiles & $15 \%$ & $10 \%$ & $6 \%$ & $6 \%$ & $8 \%$ & $5 \%$ & $8 \%$ & $7 \%$ & $7 \%$ & $3 \%$ \\
Basophils & $0 \%$ & $0 \%$ & $0 \%$ & $0 \%$ & $0 \%$ & $0 \%$ & $1 \%$ & $0 \%$ & $1 \%$ & $0 \%$ \\
Eosinophils & $0 \%$ & $0 \%$ & $0 \%$ & $0 \%$ & $0 \%$ & $0 \%$ & $0 \%$ & $1 \%$ & $1 \%$ & $0 \%$ \\
Atypical leukocytes & $0 \%$ & $0 \%$ & $0 \%$ & $0 \%$ & $0 \%$ & $0 \%$ & $0 \%$ & $0 \%$ & $0 \%$ & $0 \%$ \\
\hline
\end{tabular}

\section{Discussion}

We found MHV-78 and its antigen in blood, lungs, spleen, peritoneal macrophages, thymus, lymph nodes, bone marrow and mammary glands. The primary site of viral multiplication were lungs from which the virus spread to other organs of lymphatic system by haematogenous route. MHV-Šmava was lethal for newborn suckling mice which died 15-16 days after oral infection (Mistríková et al. 2002) similarly as we observed in mice infected with MHV-78. MHV-72 was frequently lethal for newborn mice that died 5-9 days after oral infection in contrast to 14- and 21-day-old mice did not show apparent symptoms 
of illness (Mistríková et al. 1994). In our experiments 4-6-week-old mice infected with MHV-78 did not show apparent symptoms of illness in the course of acute infection while $48 \%$ of 6-week-old mice infected with MHV-68 developed clinical signs and symptoms of illness at that time (Sunil-Chandra et al. 1992a). We detected the highest infectious titer of MHV-78 during the acute infection between days 9 and 28 in lungs in comparison with the MHV-Šumava, reaching the highest titer in lungs on days 7-14 p.i. (Mistríková et al. 2002). Intranasal inoculation with MHV-68 leads to an initial lung infection also but in comparison with MHV-Šumava (Mistríková et al. 2002) and our results with MHV-78 one week earlier with peak titers of virus in lungs 1 and 7 days p.i. (Sunil-Chandra et al. 1992a).We detected the virus in mammary glands on days 3, 28, 60, 122 and 180 p.i. This finding also indicates the possibility of secretion of the virus by maternal milk similarly to EBV (Junker et al. 1991). The EBV-induced infectious mononucleosis (IM) is a benign self-limited lymphoproliferative disease characteristic by expansion of lymphoid cells into atypical lymphocytes (To m kin s on et al. 1987). We have observed the presence of atypical lymphocytes (leukocytes) in the blood first in immunocompetent mice infected with MHV72 (Mistríková and Mrmusová 1998) and later in T cell-deficient nude mice (Rašlová et al. 2000). Atypical leukocytes observed in MHV-72-infected mice could be classified as lymphoblasts (developing stages during maturation of lymphocytes), myeloblasts and promyelocytes (developing stages during maturation of neutrophile polymorphonuclear leukocytes) as well as in patients with myeloid leukemia. Also these atypical mouse leukocytes were highly similar in shape to those leukocytes observed in a patient suffering from infectious mononucleosis (Mistríková and Mrmusová 1998). The persistence of the virus in spleen, thymus and bone marrow for a long time confirmed the affinity of MHV78 to lymphatic system. In chronic phase of infection BALB/c mice developed tumours, after MHV-78 infection (7\%), MHV-68 (11\%), MHV-72 (13\%), MHV-Šumava (14.6\%) (Mistríková et al. 2000). Presented results proved that MHV-78 is a lymphotropic virus, with oncogenic potential, and very similar with other MHV isolates in some virological and pathogenetic features.

\section{Patogenetické vlastnosti myšacieho lymfotropného gamaherpesvírusu}

Balb/c myši sme infikovali intranasálne myšacím lymfotropným gamaherpesvírusom izolátom 78 (MHV-78). V priebehu 180 dní po infekcii sme dokazovali v rôznych orgánoch vírus metódou kokultivácie s permisívnou bunkovou líniou VERO a metódou nepriamej imunofluorescencie využívajúc monoklonálne protilátky pripravené proti MHV. Najvyšší titer vírusu MHV-78 sme pozorovali počas akútnej infekcie na 15.deň v plúcach a na 7 . a 15.deň $\mathrm{v}$ krvi. $\mathrm{V}$ neskorších intervaloch infekcie bol vírus dokazovaný $\mathrm{v}$ slezine, peritoneálnych makrofágoch, v týmuse, v kostnej dreni a mliečnych žlazách. Neskôr sme robili analýzu diferenciálneho krvného obrazu (DKO) zdravých/kontrolných a vírusom infikovaných BALB/c myší. Získané výsledky ukázali, že infekcia MHV-78 bola sprevádzaná zmenami v počte leukocytov a kvalite DKO v korelácii s trvaním infekcie. V porovnaní s kontrolnou skupinou, myši infikované MHV-78 mali zvýšený počet leukocytov, s najvyšším počtom na 15.deň a 122.deň po infekcii a zvýšené leukocyty boli spájané s objavením sa atypických leukocytov. V akútnej fáze infekcie (do 30 dní po inf.) frekvencia atypických leukocytov sa zvýšila s maximom na 15.deň po infekcii. Podobné zvýšenie frekvencie týchto buniek bolo pozorované počas perzistentnej infekcie ( 30 dní po inf.) s maximom na 120.deň po inf. Približne 7\% BALB/c myší infikovaných MHV-78 vyvinulo nádor. Bunky derivované $\mathrm{z}$ nádoru boli pozitívne na vírusový antigén. Tieto výsledky ukázali, že MHV-78 je lymfotropný, onkogénny a velmi podobný MHV-68, MHV-72, MHV-76 a MHV-Šumava v niektorých virologických a patogenetických vlastnostiach. 


\section{Acknowledgements}

This work has been supported by the grant No.1/9311/02 of the Scientific Grant Agency of the Ministry of Education of Slovak Republic and Slovak Academy of Sciences.

The authors claim that all procedures using animals were performed in accordance with the European Convention for the Protection of Vertebrate Animals Used for Experimental and Other Scientific Purposes from 1986.

\section{References}

BLAŠKOVIČ, D, STANČEKOVÁ, M, SVOBODOVÁ, J, MISTRÍKOVÁ, J 1980: Isolation of five strains of herpesviruses from two species of free living small rodents. Acta virol 24: 468

EFSTATHIOU, S, HO, YM, MINSON, AC 1990a: Cloning and molecular characterization of the murine herpesvirus 68 genome. J Gen Virol 71: 1355-1364

EFSTATHIOU, S, HO, YM, HALL, S, STYLES, CJ, SCOTT, SD, GOMPELS, UA 1990b: Murine herpesvirus 68 is genetically related to the gammaherpesviruses Epstein-Barr virus and herpesvirus saimiri. J Gen Virol 71: 1365-1372

JUNKER, AK, THOMAS, EE, RADCLIFFE, A, FORSYTH, RB, DAVIDSON, AGF, RYMO, L 1991: EpsteinBarr virus shedding in breast milk. Amer J Med Sciences 302: 220-223

MACKETT, M, STEWART, JP, PEPPER, S de V, CHEE, M, EFSTATHIOU, S, NASH, AA, ARRAND, JR 1997: Genetic content and preliminary transcriptional analysis of a representative region of murine gammaherpesvirus 68. J Gen Virol 78: 1425-1433

MISTRÍKOVÁ, J, REMEŇOVÁ, A, LEŠŠO, J, STANČEKOVÁ, M 1994: Replication and persistence of murine herpesvirus 72 in lymphatic system and peripheral blood mononuclear cells of BALB/c mice. Acta virol 38: 151156

MISTRÍKOVÁ, J, MRMUSOVÁ, M 1998: Detection of abnormal lymphocytes in the blood of BALB/c mice infected with murine gammaherpesvirus strain 72: the analogy with Epstein-Barr virus infection. Acta virol 42: $79-82$

MISTRÍKOVÁ, J, MOŠKO, T, MRMUSOVÁ, M 2002: Pathogenetic characterization of a mouse herpesvirus isolate Sumava. Acta virol 46: 41-46

RAJČÁNI, J, BLAŠKOVIČ, D, SVOBODOVÁ, J, ČIAMPOR, F, HUČKOVÁ, D, STANEKOVÁ, D 1985: Pathogenesis of acute and persistent murine herpesvirus infection in mice. Acta virol 29: 51-60

RAJČÁNI, J, BUSTAMANTE de CONTRERAS, LR, SVOBODOVÁ, J 1987: Corneal inoculation of murine herpesvirus in mice, the absence of neural spread. Acta virol 31: 25-30

RAŠLOVÁ, H, MISTRÍKOVÁ, J, KÚDELOVÁ, M, MISHAL, Z, SARASIN, A, BLANGY, D, BEREBBI, M 2000: Immunophenotypic study of atypical lymphocytes generated in peripheral blood and spleen of nude mice after MHV-72 infection. Viral Immunol 13: 313-327

van REGENMORTEL, MHV, FAUQUET, CM, BISHOP, DHL, CARSTENS, EB, ESTES, MK, LEMON, SM, MANILOFF, J, MAYO, MA, McGEOCH, DJ, PRINGLE, CR, WICKNER, RB 2000: Virus Taxonomy. Seventh Report of the International Committee on Taxonomy of Viruses. Academic Press, San Diego, San Francisco, New York, Boston, London, Sydney, Tokyo, p. 1162

REICHEL, M, MATIS, J, LEŠŠO, J, STANČEKOVÁ, M 1991: Polypeptides synthesized in rabbit cells infected with murine herpesvirus (MHV): a comparison of proteins specified by various MHV strains. Acta virol 35: 268275

SUNIL-CHANDRA, NP, EFSTATHIOU, S, ARNO, J, NASH, AA 1992a: Virological and pathological features of mice infected with murine gammaherpesvirus 68. J Gen Virol 73: 2347-2356

SUNIL-CHANDRA, NP, EFSTATHIOU, S, NASH, AA 1992b: Murine gammaherpes-virus 68 establishes a latent infection in mouse B lymphocytes in vivo. J Gen Virol 73: 3275-3279

SVOBODOVÁ, J, BLAŠKOVIČ, D, MISTRÍKOVÁ, J 1982: Growth characteristics of herpesviruses isolated from free living small rodents. Acta virol 26: 256-263

TOMKINSON, BE, WAGNER, DK, NELSON, DL, SULLIVAN, JL 1987: Activated lymphocytes during acute Epstein-Barr virus infection. J Immunol 139: 3802-3807

VIRGIN IV, HW, LATREILLE, P, WAMSLEY, P, HALLSWORTH, K, WECK, KE, dal CANTO, AJ, SPECK, SH 1997: Complete sequence and genomic analysis of murine gammaherpesvirus 68. J Virol 71: 5894-5904 
Plate III

Mrmusová-Šupolíková M. et al.: Pathogenesis... pp. 371-376

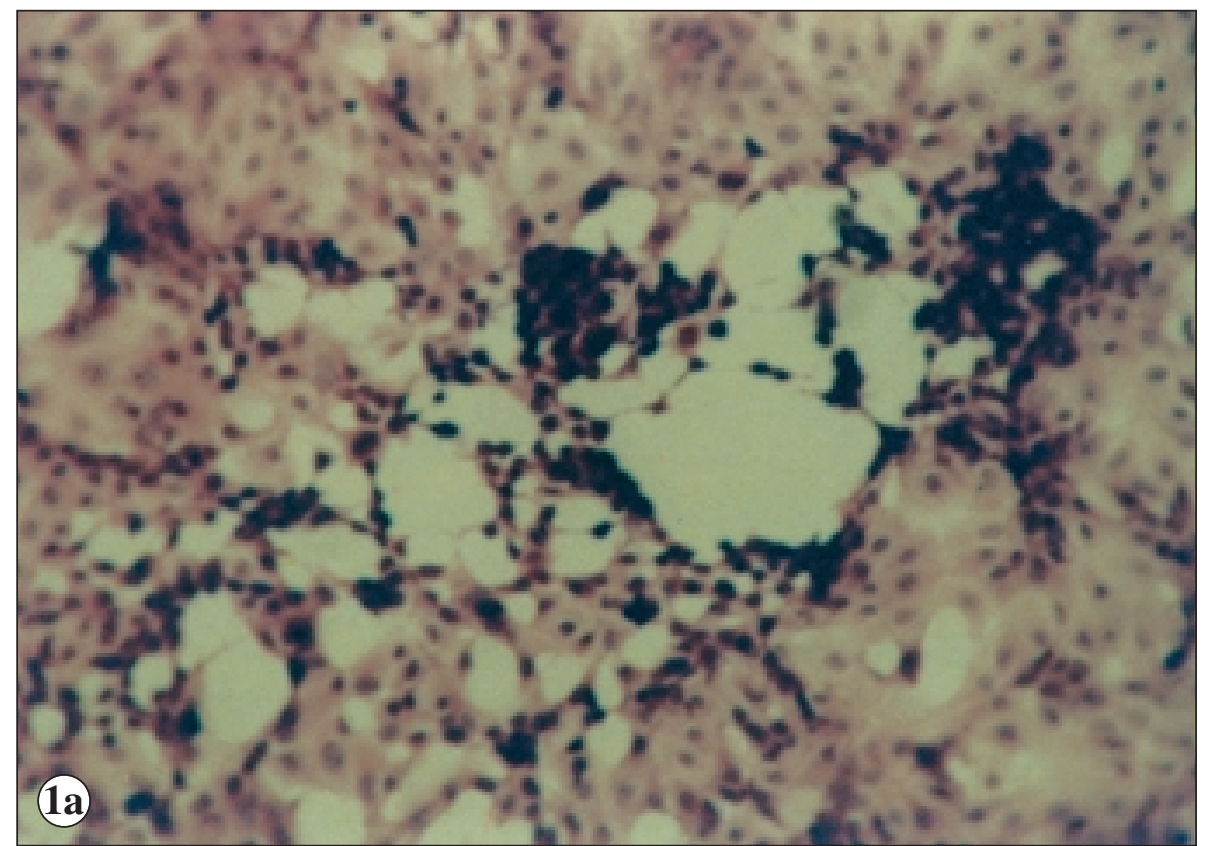

Fig. 1a. VERO cells at 72 hours p.i. with a suspension from lungs of MHV-78 infected BALB/c mice (magnification $\times 100$ ).

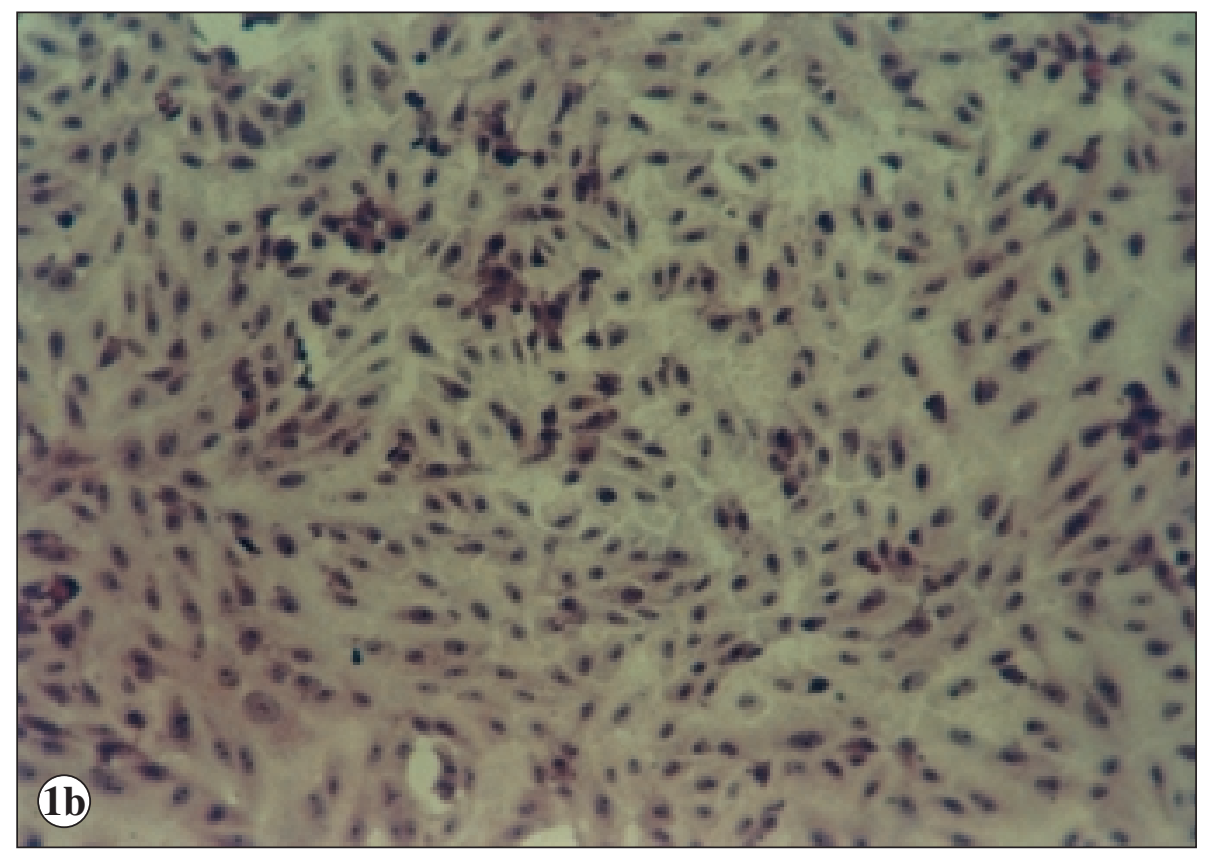

Fig. 1b. VERO cells at 72 hours with a suspension from lungs of a control (non-infected) BALB/c mice (magnification $\times 100$ ). 


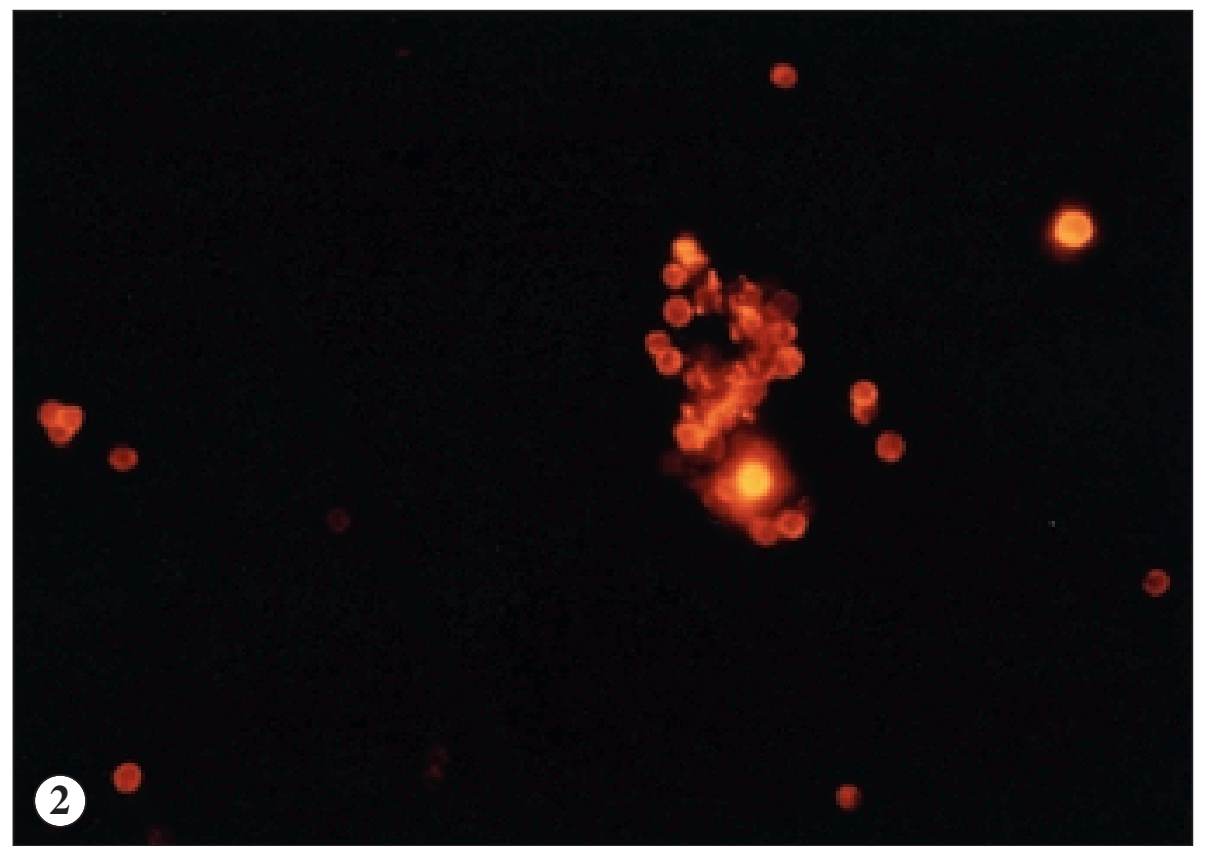

Fig. 2. Positive immunofluorescence of MHV-78 antigen in splenocytes from BALB/c mice 60 days p.i. (magnification $\times 360$ ) .



Fig. 3. Atypical leukocytes (blastic forms of leukocytes) observed in differential white blood cell count of $\mathrm{BALB} / \mathrm{c}$ mice infected with MHV-78 (magnification $\times 1000)$. 
Plate V



Fig. 4. Cell line derived from tumor developed in BALB/c mice 240 d.p.i. with MHV-78. Cell line in $9^{\text {th }}$ passage (magnification $\times 360$ ).

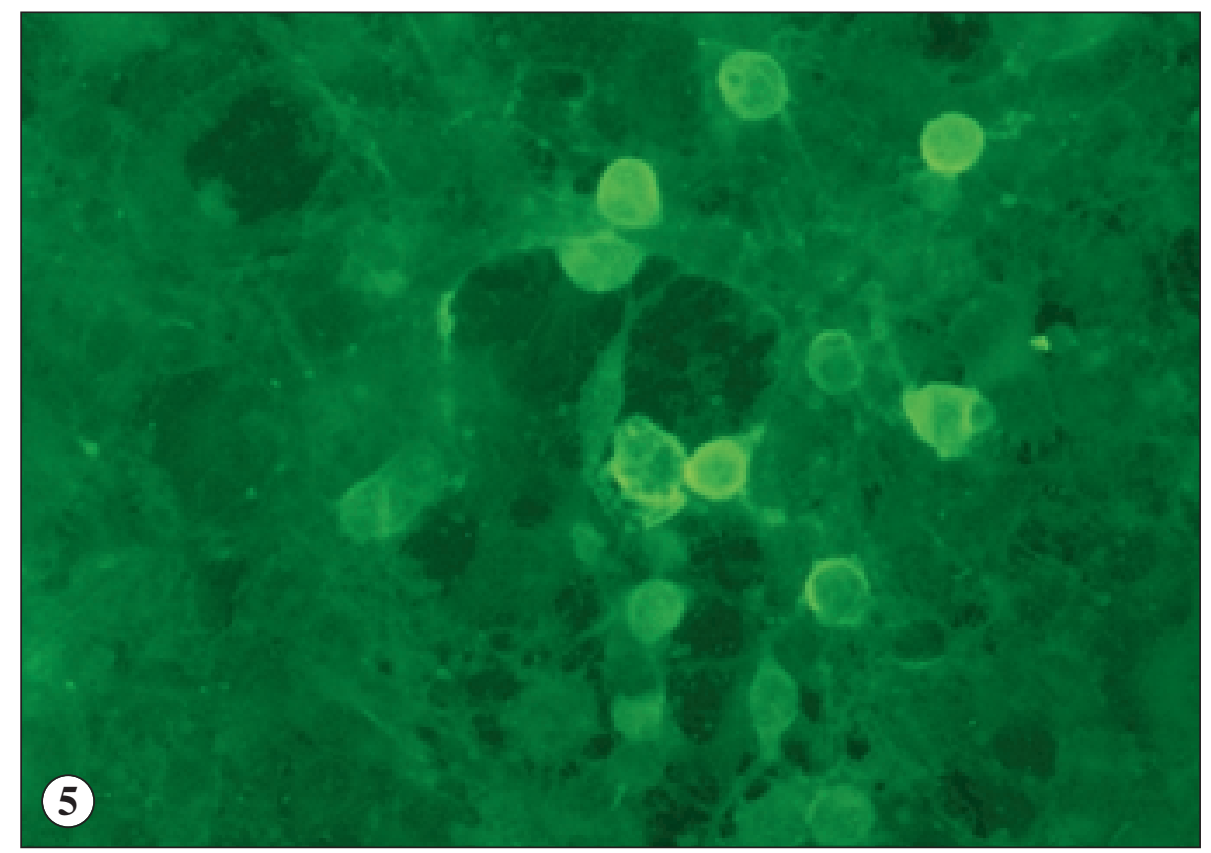

Fig. 5. Positive immunofluorescence of MHV-78 antigen in tumor cell line (magnification $\times 720$ ). 